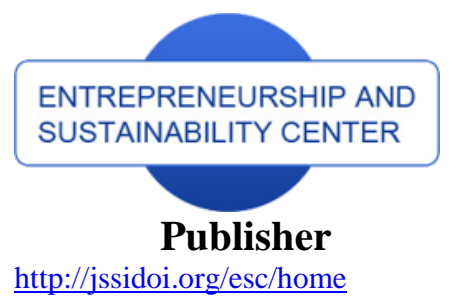

http://]ssidoi.org/esc/home
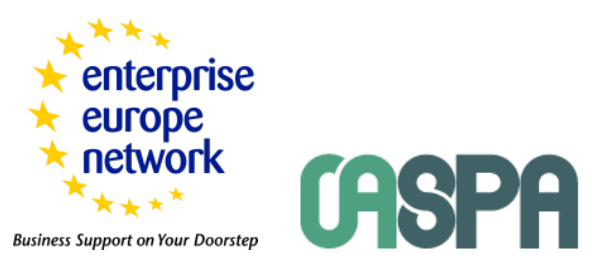

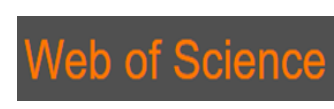

1) Clarivate

\title{
THE TAX MECHANISM OF MANAGING THE PROCESS OF FORMATION OF INFORMATION ECONOMY IN MODERN RUSSIA
}

\author{
Olga Vandina ${ }^{1}$, Zoya Mkrtychan ${ }^{2}$, Igor Denisov ${ }^{3}$, Yelena Vechkinzova ${ }^{4}$ \\ ${ }^{1,2}$ Armavir University of Pedagogics, 352901, South Federal District, Krasnodar region, Armavir, \\ Rosa Luxemburg Street, d.159, Russia \\ ${ }^{3}$ Plekhanov Russian University of Economic, 117997, Moscow, Stremyanny lane 36, Russia, \\ ${ }^{4} V$. A. Trapeznikov Institute of Control Sciences of Russian Academy of Sciences 65 \\ Profsoyuznaya Street, Moscow 117997, Russia \\ E-mails: ${ }^{1,2}$ vandina08@mail.ru,$\underline{3}$ denisov.id@ gmail.com,${ }^{4}$ kvin07@list.ru
}

Received 29 May 2018; accepted 10 October 2018; published 30 December 2018

\begin{abstract}
The purpose of the work is to determine the features of application of tax measures for stimulation of formation of information economy in modern Russia, to substantiate the perspectives of their expanded application, and to develop practical recommendations and to compile a tax mechanism of managing the process of formation of information economy in modern Russia. The authors use the systemic approach, methods of statistical analysis (analysis of statistical data), analysis of causal connections (logical analysis), and formalization (graphic presentation of authors' conclusions and recommendations). The authors conduct a complex evaluation of the level of development of information economy of modern Russia (as of 2018) based on the data of the National Research University "Higher School of Economics", IMD World Competitiveness Center, and the World Economic Forum and determine that for building competitive, highly-effective, and sustainable information economy in modern Russia, it is necessary to pay attention to the issues of development of E-government and the spheres of new information and communication technologies. The authors also perform a complex empirical analysis of the practice of taxation in modern Russia, which showed that tax measures that are used for managing the process of formation of information economy in modern Russia are contradictory and insufficient for achieving substantial progress in formation of information economy. As a result, it is determined that the current Russian tax mechanism of managing the process of formation of information economy in modern Russia could be characterized as restraining. Its drawbacks, related to insufficient attention to underdeveloped characteristics of information economy and contradiction, could be solved with the developed tax mechanism of managing the process of formation of information economy in modern Russia, which could be characterized as stimulating.
\end{abstract}

Keywords: tax mechanism; management; information economy; modern Russia

Reference to this paper should be made as follows: Finogentova, O.; Tokarev, V.; Petrenko, M.; Primak, T. 2018. Acceptance criterion of state coercion in contemporary society, Entrepreneurship and Sustainability Issues 6(2): 830-839. http://doi.org/10.9770/jesi.2018.6.2(24)

JEL Classifications: E62, M15, O47 


\section{Introduction}

Information economy is a result of the vision of the future of the modern global economic system. Formation of information economy is the most preferable variant of development of economies, including modern Russia, as it combines the following advantages. Firstly, high-tech. Specialization in production and dissemination of information technologies and products, which have stable high demand in domestic and global markets, allows obtaining a status of a high-tech country and guaranteeing sustainable development of economy in the long-term. Secondly, high effectiveness. Informatization allows optimizing economic activities by its full or partial authomatization, due to which high labor efficiency is achieved in economy. Thirdly, high competitiveness. Informatization economy allows manufacturing new products and using more efficient means of its promotion and sales, gaining advantages from "scale effect" and achieving the best price/quality ratio.

Striving for such advantages, modern Russia implements measures in various spheres that are aimed at stimulation of quick formation of information economy. These measures cover development of normative and legal provision and creation of telecommunication infrastructure and preparation of personnel for information economy, etc. At that, according to our hypothesis, tax measures are not considered sufficiently due to underestimation of their potential.

The purpose of the work is to determine the peculiarities of application of tax measures of stimulation of formation of information economy in modern Russia, to substantiate the perspectives of their expanded application, to develop practical recommendations, and to compile a tax mechanism of managing the process of formation of information economy in modern Russia.

\section{Materials and Method}

Information economy is a popular subject for conducting modern scientific research. It is studies in a lot of works of such scholars as (Bondarenko et al., 2017), (Gladilin et al., 2019), (Protopopova et al., 2019), (Vandina, 2016), and (Yudina et al., 2017).

At the same time, there's no system in studying the information economy, which leads to absence of its common treatment. Thus, scientific literature has similar terms - digital economy, Industry 4.0, Internet economy, etc. which are either synonyms or separate manifestations of information economy (e.g. Prause, Atari, 2017; Vlasov et al., 2018).

As a result of performed systematization of existing scientific data in the sphere of studying information economy, we determined its following characteristics:

- Mass usage of new information and communication technologies (PC, mobile devices, the Internet, etc.) by population;

- full (E-government) or partial (implementation into separate business processes) foundation of business structures on new information and communication technologies;

- usage of new information and communication technologies in the process of provision of government services (E-government);

- leading development of the spheres of telecommunication infrastructure (accessibility of high-speed Internet, mobile communications, etc.);

- high level and intensive development or specialization of economy in the spheres of new information and communication technologies. 
The issues of application of tax measures for managing the process of formation of information economy are poorly studied and are viewed indirectly in scientific works (Bogoviz et al., 2017), (Gupta et al., 2015), and (Sukhodolov et al., 2018), (Abbas, 2018), (Fokina et al., 2018), (Stroeva et al., 2019), (Zaytsev et al., 2019), (Zmiyak et al., 2019). The authors use the systemic approach and methods of statistical analysis (analysis of statistical data), analysis of causal connections (logical analysis), and formalization (graphic presentation of authors' conclusions and recommendations).

\section{Information economy in Russia}

Normative and legal provision of formation of information economy in modern Russia consists of the Strategy of development of information society of the RF for 2017 - 2030, adopted by the Decree of the President of the RF dated May 9, 2017 No. 203 (President of the RF, 2018) and the Program "Digital economy of the RF", adopted by the Decree of the Government of the RF dated July 28, 2017, No. 1632-r (Government of the RF, 2018).

Studying these documents, we came to the conclusion that they aim the process of formation of information economy in Russia at provision of its global competitiveness with insufficient attention to practical implementation of the possibilities of optimization of economic activities and sustainable development of the domestic economic system. The results of the performed complex evaluation of the level of development of information economy modern Russia (as of 2018), based on the data of the National Research University "Higher School of Economics", IMD World Competitiveness Center, and the World Economic Forum, are presented in Table 1.

Table 1. Level of development of information economy of modern Russia (as of 2018)

\begin{tabular}{|c|c|c|c|}
\hline \multirow{2}{*}{$\begin{array}{c}\text { Characteristics of information } \\
\text { economy }\end{array}$} & $\begin{array}{c}\text { According to National } \\
\text { Research University "Higher } \\
\text { School of Economics", \% of } \\
\text { selection (explanation) }\end{array}$ & $\begin{array}{c}\text { According to IMD } \\
\text { World Competitiveness } \\
\text { Center, points 1-100 (position } \\
\text { out of 63) }\end{array}$ & $\begin{array}{c}\text { According to the World } \\
\text { Economic Forum, points 1-7 } \\
\text { (position out of 139) }\end{array}$ \\
\hline $\begin{array}{c}\text { Usage of the ICT* by } \\
\text { population }\end{array}$ & 74.8 (share of Internet users) & 39 & $5.3(40)$ \\
\hline $\begin{array}{c}\text { Usage of the ICT* by } \\
\text { business }\end{array}$ & 85.7 (share of Internet users) & 62 & $3,6(67)$ \\
\hline $\begin{array}{c}\text { Usage of the ICT* by the } \\
\text { state }\end{array}$ & $\begin{array}{c}51.3 \text { (share of electronic } \\
\text { services obtained by users) }\end{array}$ & 43 & $4.4(44)$ \\
\hline $\begin{array}{c}\text { Development of ICT*- } \\
\text { infrastructure }\end{array}$ & $\begin{array}{c}38.4 \text { (as compared to other } \\
\text { infrastructure) }\end{array}$ & 38 & $4.7(52)$ \\
\hline $\begin{array}{c}\text { Development of spheres of } \\
\text { the ICT* }\end{array}$ & 2.9 (share of GDP) & 25 & $3.7(38)$ \\
\hline On the whole & - (data are absent) & 65.207 (40) & $4.5(41)$ \\
\hline
\end{tabular}

*ICT - new information and communication technologies

Source: compiled by the authors based on: (National Research University "Higher School of Economics", 2018), (IMD World Competitiveness Center, 2018), (World Economic Forum, 2018).

The data of Table 1 show that the level of development of telecommunication infrastructure in Russia is rather high, which emphasizes large potential of formation of information economy. The level of usage of new information and communication technologies by society and business is rather high in modern Russia.

However, despite the formally high level of usage of new information and communication technologies by the state, according to the data of IMD World Competitiveness Center and the World Economic Forum, the data of 
the National Research University "Higher School of Economics" show that they are used for internal purposes with insufficient attention to provision of electronic government services to interested parties (population and business). The level of development of the spheres of new information and communication technologies is formally high, which is shown by the data of IMD World Competitiveness Center and the World Economic Forum, but their contribution into formation of Russia's GDP is very small, constituting $2.9 \%$, according to the National Research University "Higher School of Economics".

Thus, the performed analysis showed imbalance of development of information economy in modern Russia, of which the most probably reason is state's aiming at receipt of quick formal results. Therefore, for formation of competitive, highly-effective, and sustainable information economy in modern Russia, it is necessary to pay attention to the issues of development of E-government and spheres of new information and communication technologies.

\section{Tax measures that are used for managing the process of formation of information economy in modern Russia}

The performed complex empirical analysis of the taxation practice in modern Russia showed that there have been intensive transformation processes, which consist in the following:

- increase of control over electronic financial operations of population (individuals), by expansion of authorities of the tax service as to inspections (with potential application of the Big data technology) for obtaining "shadow" revenues;

- planning the large growth of current tax rates and introduction of additional taxes for purchase of products in the Internet (E-commerce);

- implementation of requirements to mandatory electronic registration of all trading operations via online mechanisms with direct connection to the tax service for preventing the "shadow" revenues of business and for development of electronic tax administration.

The above tax measures, which are used for managing the process of formation of information economy in modern Russia, emphasize state's striving for usage of technological opportunities that open in the conditions of information economy, in the national interests (for increase of collection of taxes) with insufficient attention to interests of the population and business. Moreover, these measures could have a reverse effect for information economy, related to limitation of electronic payments due to voluntary refusal of population and business and to reduction of popularity of E-commerce.

At the same time, online mechanisms allow modern Russian companies to develop electronic document turnover and electronic tax accounting and will stimulate authomatization of the system of tax administration, which is a positive tendency in the aspect of formation of information economy. However, it is obvious that tax measures that are used for managing the process of formation of information economy in modern Russia are contradictory and insufficient for achieving large progress in formation of information economy and, therefore, require correction.

\section{Perspectives and recommendations for improving the application of tax measures for managing the process of formation of information economy in modern Russia}

The following tax mechanism of managing the process of formation of information economy in modern Russia (Figure 1) is offered for practical application. 
Purpose: tax stimulation of the process of formation of information economy in modern Russia

- introduction of a special tax regime for online companies;

- reduction of tax rates for electronic purchases for consumers.

companies*;

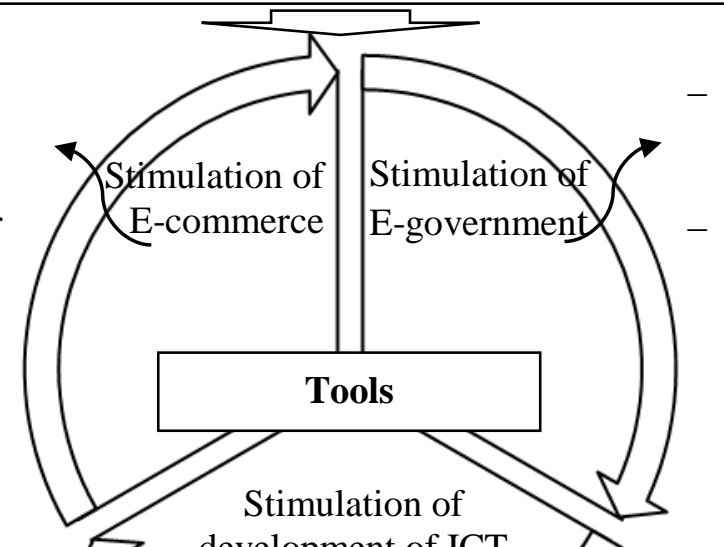
development of ICT spheres*

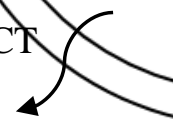

provision of subsidies for payment of taxes in the electronic cabinet; provision of subsidies for payment of taxes with the help of electronic payments.

\footnotetext{
Result: creation of favorable conditions and provision of interest of economic subjects in informatization, quick formation of information economy in modern Russia
}

As is seen from Figure 1, the developed mechanism is aimed at tax stimulation of the process of formation of information economy in modern Russia. In view of the determined characteristics of information economy in modern Russia, we deem it necessary to use tax measures for stimulating:

- E-commerce, by introduction of a special tax regime for online companies and reduction of tax rate for online purchases for consumers;

- E-government by provision of subsidies for payment of taxes in online cabinet and provision of subsidies for payment of taxes with the help of online payments;

- development of the spheres of information and communication technologies by establishment of preferential conditions of taxation for ICT companies and provision of tax subsidies for the companies that use new ICT.

This will allow creating favorable conditions and ensuring interest of economic subjects in informatization, due to which quick formation of information economy in modern Russia will become possible.

Practical implementation of the presented tax mechanism of managing the process of formation of information economy in modern Russia (Figure 1) is to be conducted according to the following algorithm. At the first stage of this process, it is offered to conduct information and marketing support for future measures in the sphere of tax stimulation of formation of information economy in modern Russia.

Firstly, all interested parties should be informed about priority of formation of information economy for successful development of socio-economic system of modern Russia in the long-term. At that, it is expedient to focus on the current level of informatization of the Russian society and economy, its comparison to the level of informatization of socio-economic systems of leading developed countries (OECD countries), substantiation of advantages of information economy by the example of successful global experience of its formation, and 
emphasizing the necessity for formation of information economy for supporting competitiveness and sustainability of development of socio-economic system of Russia in the long-term.

Secondly, it is expedient to conduct sociological surveys and statistical studies for:

- $\quad$ determining the level of support for future tax measures in the sphere of tax stimulation of formation of information economy in modern Russia by society and entrepreneurship;

- evaluating the level of information awareness (mastering of new information and communication technologies at the user's level) of various categories of population and the level of information competence (level of mastering of new information and communication technologies at the professional's level) of representatives of various categories in the Russian labor market;

- determining the level of readiness, actuality, and effectiveness of infrastructural provision (material \& technical and telecommunication) of formation of information economy in modern Russia;

- determining the level of readiness of entrepreneurial structures for implementing the investment and innovational projects that are aimed at formation of information economy in modern Russia;

- interest of various categories of population in formation of information economy in modern Russia and their readiness for financing of this process by the corresponding spending of tax revenues of the federal budget and purchase of products (goods, works, and services) of information economy.

Thirdly, the state has to collect feedback from all interested parties (society and entrepreneurship) regarding:

- $\quad$ present preconditions for formation of information economy in modern Russia;

- $\quad$ potential barriers on the path of formation of information economy in modern Russia;

- $\quad$ technical, financial, and social risks of formation of information economy in modern Russia;

- $\quad$ perspective solutions to current problems of formation of information economy in modern Russia.

The tools of information and marketing support for future measures in the sphere of tax stimulation of formation of information economy in modern Russia should be as follows:

- $\quad$ social advertising and PR: it is possible to form positive attitude and approval from society and entrepreneurship for future measures in the sphere of tax stimulation of formation of information economy in modern Russia;

- Internet marketing: it allows for highly-effective marketing communications between the state, society, and entrepreneurship with the help of marketing via state and private Internet sites, e-mail marketing, and social networks marketing.

At the second stage of this process, it is recommended to involve all interested parties in discussion of planned tax reforms in the sphere of tax stimulation of formation of information economy in modern Russia. This envisages development of preliminary projects of tax reforms in the sphere of tax stimulation of formation of information economy in modern Russia. At that, it is recommended to use outsource for access for original and perspective ideas of interested parties - though, main responsibilities for preparation of projects of tax reforms are set on the state.

Secondly, it is necessary to openly discuss projects of tax reforms in the sphere of tax stimulation of formation of information economy in modern Russia with participation of representatives of interested parts of society and entrepreneurship. For this, it is necessary to observe the following conditions:

- direct participation (personal presence) of representatives of interested parts of society in discussion of the Government of the RF of tax reforms in the sphere of tax stimulation of formation of information economy in modern Russia; 
The International Journal

ENTREPRENEURSHIP AND SUSTAINABILITY ISSUES

ISSN 2345-0282 (online) http://jssidoi.org/jesi/

2018 Volume 6 Number 2 (December)

http://doi.org/10.9770/jesi.2018.6.2(24)

- $\quad$ information support, extramural and remote consultations by representatives of the public for Government of the RF on the issues of tax reforms in the sphere of tax stimulation of formation of information economy in modern Russia;

- $\quad$ openness of the process of discussion by the Government of the RF of tax reforms in the sphere of tax stimulation of formation of information economy in modern Russia (informing all interested parties via web-sites and social networks).

Thirdly, it is expedient to correct the projects of tax reforms in the sphere of tax stimulation of formation of information economy in modern Russia and adopt them in the form that harmonizes the interests of all interested parties (various categories of society and entrepreneurship). All offers should be taken into account, discussed, and, if possible, accepted by the Government of the RF, with achievement of the maximum level of detalization of adopted tax reforms in the sphere of tax stimulation of formation of information economy in modern Russia.

At the third stage of this process, it is offered to implement the adopted reforms and to collect feedback from interested parties for their optimization (improvement and correction). It is recommended to implement these reforms in a test regime on certain territories of the RF (e.g., Moscow Oblast or Leningrad Oblast) and/or within special economic areas. This will allow determining gaps, contradictions, and other drawbacks of adopted tax reforms in the sphere of tax stimulation of formation of information economy in modern Russia.

All determined drawbacks should be shown to the public and discussed. After that, it is possible to implement the adopted, testes, and optimized tax reforms in the sphere of tax stimulation of formation of information economy in modern Russia in the whole country. It is recommended to implement these reforms gradually during 3-5 years, for avoiding serious social shock and timely determination and elimination of drawbacks of these reforms.

At the fourth stage of this process, it is recommended to conduct the state and public monitoring and control over effectiveness of implemented measures in the sphere of tax stimulation of formation of information economy in modern Russia, to accumulate experience, and to plan new reforms in this sphere. During monitoring, it is recommended to use the following criteria of effectiveness of implemented measures in the sphere of tax stimulation of formation of information economy in modern Russia:

- $\quad$ increase of the number and turnover of online companies in Russia as a result of implementing measures in the sphere of tax stimulation of formation of information economy;

- $\quad$ growth of the number and cost of online purchases of Russian consumers as a result of implementing measures in the sphere of tax stimulation of formation of information economy;

- $\quad$ growth of the share of online entrepreneurship in the general structure of Russian entrepreneurship as a result of implementation of measures in the sphere of tax stimulation of formation of information economy;

- level of development of the spheres of information and communication technologies as a result of implementing the measures in the sphere of tax stimulation of formation of information economy;

- number of companies that use new information and communication technologies as a result of implementing the measures in the sphere of tax stimulation of formation of information economy;

- $\quad$ share of taxes paid by population and entrepreneurship in online cabinet as a result of implementation of measures in the sphere of tax stimulation of formation of information economy;

- $\quad$ share of taxes paid by population and entrepreneurship with the help of online payments as a result of implementation of measures in the sphere of tax stimulation of formation of information economy.

During monitoring and control over effectiveness of implemented measures in the sphere of tax stimulation of formation of information economy in modern Russia, it is necessary to use the following principles:

principle of objectivity: rejecting subjectivism and founding on statistical data on implementation of measures in the sphere of tax stimulation of formation of information economy in modern Russia; 
The International Journal

ENTREPRENEURSHIP AND SUSTAINABILITY ISSUES

ISSN 2345-0282 (online) http://jssidoi.org/jesi/

2018 Volume 6 Number 2 (December)

http://doi.org/10.9770/jesi.2018.6.2(24)

- $\quad$ principle of complex character: consideration of all factors and future perspectives of implementation of measures in the sphere of tax stimulation of formation of information economy in modern Russia;

- $\quad$ principle of effectiveness: monitoring and control are to be conducted with the usage of new information and communication technologies with the help of Internet surveys and statistical research.

As a result of monitoring, drawbacks of the implemented measures are found, and perspectives of future measures in the sphere of tax stimulation of formation of information economy in modern Russia are determined. That is, the offered algorithm of implementation of the offered tax mechanism of managing the process of formation of information economy in modern Russia is cyclic, which ensures continuity and systemic character of this process.

\section{Conclusions}

It is possible to conclude that the offered hypothesis is proved - tax measures are used in modern Russia as to certain characteristics of information economy (as to usage of new information and communication technologies by population, business, and state) and have contradictory effect; very often, instead of stimulating the formation of information economy, they limit its development due to orientation at primarily state interests and damaging the interests of economic subjects (population and business).

The modern Russian tax mechanism of managing the process of formation of information economy in modern Russia could be characterized as restraining. Its drawbacks, related to insufficient attention to underdeveloped characteristics of information economy (primarily, the spheres of new information and communication technologies) and described contradiction (emergence of reverse effects), could be overcome by the developed authors' tax mechanism of managing the process of formation of information economy in modern Russia, which could be described as stimulating.

This mechanism is aimed at provision of tax stimuli (preferences in the form of tax subsidies) for development of the spheres of new information and communication technologies, as well as popularization of these technologies among population and business (in the aspect of E-commerce) and further practical development of the system of E-government. The offered mechanism showed large potential of tax measures as to stimulation of formation of information economy in modern Russia. Its implementation will allow increasing and supplementing positive effective from other measures and accelerating the process of formation of information economy in modern Russia.

\section{References}

Abbas, S.A. (2018). Entrepreneurship and information technology businesses in economic crisis. Entrepreneurship and Sustainability Issues 5(3): 682-692 http://dx.doi.org/10.9770/jesi.2018.5.3(20)

Bogoviz, A.V., Ragulina, Y.V., Komarova, A.V., Bolotin, A.V., Lobova, S.V. (2017). Modernization of the approach to usage of region's budget resources in the conditions of information economy development. European Research Studies Journal 20(3): 570-577. Retrieved from https://www.scopus.com/record/display.uri?eid=2-s2.0-85028943384\&origin=resultslist\&sort=plf-

$\mathrm{f} \& \mathrm{src}=\mathrm{s} \& \mathrm{st} 1=$ Modernization+of+the+approach+to+usage+of+region $\% 27 \mathrm{~s}+$ budget+resources+in+the+conditions+of +information+econom $\mathrm{y}+$ development\&st2=\&sid=3ce6465b4e82425b65ec71a6d9682fc4\&sot=b\&sdt=b\&sl=127\&s=TITLE\%28Modernization+of+the+approach + to+usage+of+region $\% 27 \mathrm{~s}+$ budget + resources+in+the+conditions+of + information+economy+development $\% 29 \&$ relpos $=0 \& \mathrm{citeCnt}=4 \&$ sea $\underline{\text { rchTerm }=}$ 
Bondarenko, I.A., Vandina, O.G., Rusetskaya, E.A., Charakhchyan, K.K. (2017). Parametric characteristics of conflict of interests between owners and managers in corporations. Journal of Advanced Research in Law and Economics 8(1), 23: 18-22. http://dx.doi.org/10.14505/jarle.v8.1(23).02

Fokina, O.V., Fufacheva, L.A., Sozinova, A.A., Sysolyatin, A.V., Bulychev, L.L. (2018). Information and communication technologies as a new vector of development of modern global economy. Espacios 39(28): 22-29. Retrieved from https://www.scopus.com/record/display.uri?eid=2-s2.0-85049862427\&origin=resultslist\&sort=plf-

$\underline{\mathrm{f} \& \mathrm{src}=\mathrm{s} \& \mathrm{st} 1=\text { Information+and+communication+technologies+as+a+new+vector+of+development+of+modern+global+economy\&st } 2=\& \mathrm{~s}}$

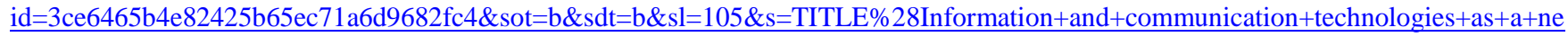
$\underline{w}+$ vector+of+development+of + modern+global+economy $\% 29 \&$ relpos $=0 \&$ citeCnt $=0 \&$ searchTerm $=$

Gladilin, A.V., Dotdueva, Z.S., Klimovskikh, Y.A., Labovskaya, Y.V., Sharunova, E.V. (2019). Establishment of Information Economy Under the Influence of Scientific and Technical Progress. Advances in Intelligent Systems and Computing 726: 46-55. http://dx.doi.org/10.1007/978-3-319-90835-9_6

Government of the RF (2018). Program “Digital economy of the RF”, adopted by the Decree of the Government of the RF dated July 28, 2017, No. 1632-r. Retrieved from http://static.government.ru/media/files/9gFM4FHj4PsB79I5v7yLVuPgu4bvR7M0.pdf

Gupta, G., Zaidi, S.K., Udo, G., Bagchi, K. (2015). The influence of theory of planned behavior, Technology Acceptance Model, and Information Systems Success Model on the acceptance of electronic tax filing system in an emerging economy. International Journal of Digital Accounting Research 15, p. 155-185. http://dx.doi.org/10.4192/1577-8517-v15_6

IMD World Competitiveness Center (2018). World Digital Competitiveness Ranking 2018 results. Retrieved from https://www.imd.org/wcc/world-competitiveness-center-rankings/world-digital-competitiveness-rankings-2018/

National Research University "Higher School of Economics" (2018). Digital economy: short statistical collection. Retrieved from https://www.hse.ru/primarydata/ice2018kr

Prause, G., Atari, S. (2017). On sustainable production networks for Industry 4.0. Entrepreneurship and Sustainability Issues 4(4): 421431. https://doi.org/10.9770/jesi.2017.4.4(2)

President of the RF (2018). Strategy of development of information society in the RF for 2017 - 2030, adopted by the Decree of the President of the RF dated May 9, 2017, No. 203. Retrieved from http://pravo.gov.ru/proxy/ips/?docbody=\&nd=102431687

Protopopova, N.I., Grigoriev, V.D., Perevozchikov, S.Y. (2019). Information and digital economy as an economic category. Advances in Intelligent Systems and Computing 726: 300-307. http://dx.doi.org/10.1007/978-3-319-90835-9_35

Petrenko D. Ulybyshev, O. Lenkova, S. Akenov. (2017). Priority Directions of Cooperation and Interaction of the Countries of the Eurasian Economic Union in the Scientific and Innovative Environment. Journal of Advanced Research in Law and Economics; 6(28), 17-29. Retrieved from https://journals.aserspublishing.eu/jarle/article/view/1868

Stroeva, O.A., Lyapina, I.R., Gryadunova, A.V., Tishaev, V.V., Shalaev, I.A. (2019). Priorities of using the new information and communication technologies in modern economy. Advances in Intelligent Systems and Computing 726: 449-455. http://dx.doi.org/10.1007/978-3-319-90835-9_53

Sukhodolov, A.P., Popkova, E.G., Kuzlaeva, I.M. (2018). Peculiarities of formation and development of internet economy in Russia. Studies in Computational Intelligence 714: 63-70. http://dx.doi.org/10.1007/978-3-319-60273-8 6

Vandina, O.G. (2016). "Just in time" system in construction industry and its competitiveness. International Journal of Economic Perspectives 10(4): 401-405. Retrieved from $\quad$ https://www.scopus.com/record/display.uri?eid=2-s2.0$\underline{85027365666 \& \text { origin }=\text { resultslist } \& \text { sort }=\text { plf- }}$

f\&src=s\&st1="Just+in+time"+system+in+construction+industry+and+its+competitiveness\&st $2=\& \operatorname{sid}=3 \mathrm{ce} 6465 \mathrm{~b} 4 \mathrm{e} 82425 \mathrm{~b} 65 \mathrm{ec} 71 \mathrm{a} 6 \mathrm{~d} 9682 \mathrm{f}$ c4\&sot=b\&sdt=b\&sl=77\&s=TITLE\%28"Just+in+time" + system + in + construction+industry+and+its+competitiveness $\% 29 \&$ relpos $=0 \&$ citeC $\underline{\mathrm{nt}=0 \& \text { searchTerm }}=$ 
The International Journal

ENTREPRENEURSHIP AND SUSTAINABILITY ISSUES

ISSN 2345-0282 (online) http://jssidoi.org/jesi/

2018 Volume 6 Number 2 (December)

http://doi.org/10.9770/jesi.2018.6.2(24)

Vlasov, A.I.; Grigoriev, P.V.; Krivoshein, A.I; Shakhnov, V.A.; Sergey S. Filin, S.S.; Migalin, V.S. (2019). Smart management of technologies: predictive maintenance of industrial equipment using wireless sensor networks. Entrepreneurship and Sustainability Issues 6(2): 489-502. http://doi.org/10.9770/jesi.2018.6.2(2)

World Economic Forum (2018). The Global Information Technology Report 2016 Innovating in the Digital Economy. Retrieved from http://www3.weforum.org/docs/GITR2016/WEF_GITR_Full_Report.pdf

Yudina, T.A., Vandina, O.G., Bogoviz, A.V., Lobova, S.V. (2017). Effectiveness of the methods of internal financial control as a guarantee of sustainability of tourism companies' development. Journal of Environmental Management and Tourism 8(4): 861-866. http://dx.doi.org/10.14505/jemt.v8.4(20).15

Zaytsev, A.G., Plakhova, L.V., Legostaeva, S.A., Zakharkina, N.V., Zviagintceva, Y.A. (2019). Establishment of Information Economy Under the Influence of Scientific and Technical Progress: New Challenges and Possibilities. Advances in Intelligent Systems and Computing 726: 3-10. http://dx.doi.org/10.1007/978-3-319-90835-9_1

Zmiyak, S.S., Ugnich, E.A., Krasnokutskiy, P.A. (2019). Generation and commercialization of knowledge in the innovational ecosystem of regional university in the conditions of information economy establishment in Russia. Advances in Intelligent Systems and Computing 726: 23-31. http://dx.doi.org/10.1007/978-3-319-90835-9_3

Short biographical note about the contributors at the end of the article (name, surname, academic title and scientific degree, duties, research interests):

Olga VANDINA, doctor of Economics, Professor, Head of the Department of Economics and Management Armavir University of Pedagogics, 352901, South Federal District, Krasnodar region, Armavir, Rosa Luxemburg Street, d.159, Russia.

ORCID ID: 0000-0003-0348-7216

Zoya MKRTYCHAN, Candidate of economic sciences Armavir University of Pedagogics, 352901, South Federal District, Krasnodar region, Armavir, Rosa Luxemburg Street, d.159, Russia.

ORCID ID: 0000-0003-0833-2395

Igor DENISOV Doctor of economics, professor, Plekhanov Russian University of Economic, 117997, Moscow, Stremyanny lane 36, Russia.

ORCID ID: 0000-0002-8718-9023

Yelena VECHKINZOVA, Candidate of economic sciences, doctoral student of the Laboratory of Economic Dynamics and Innovation Management of the V.A. Trapeznikov Institute of Control Science of the Russian Academy of Sciences, Moscow, Russia.

ORCID ID: 0000-0003-2543-625X

\footnotetext{
Copyright (C) 2018 by author(s) and VsI Entrepreneurship and Sustainability Center

This work is licensed under the Creative Commons Attribution International License (CC BY).

http://creativecommons.org/licenses/by/4.0/

(c) (i) Open Access
} 